International Journal of Engineering \& Technology, $9(1)(2020)$ 149-163
International Journal of Engineering \& Technology
SPC
Website: www.sciencepubco.com/index.php/IJET
Research paper

\title{
Modelling and control of a grid-tied power conditioning unit for a megawatt fuel cell system
}

\author{
Khlid Ben Hamad *, Mohamed Tariq Kahn \\ Department of Electrical, Electronics and Computer Engineering, Cape Peninsula University of \\ Technology, Bellville 7535, Western Cape, South Africa \\ *Corresponding author E-mail: benhamad82@gmail.com
}

\begin{abstract}
It is a reality that future development in the energy sector is founded on the utilization of renewable and sustainable energy sources. These energy sources can empower to meet the double targets of diminishing greenhouse gas emissions and ensuring reliable and cost-effective energy supply. Fuel cells are one of the advanced clean energy technologies and have demonstrated their ability to be a decent substitute to address the above-mentioned concerns. They are viewed as reliable and efficient technologies to operate either tied or non-tied to the grid and power applications ranging from domestic, commercial to industrial. Among different fuel cell technologies, proton exchange membrane is the most attractive. Its connection to the utility grid requires that the power conditioning system serving as the interface between the stack and the grid operates accordingly. This study aims to model and control a power conditioning system for the gridconnection of a megawatt fuel cell stack. Besides the grid, the system consists of a 1.54 MW/1400 V DC proton exchange membrane fuel cell stack, a 1.3 MW/600 V three-level diode clamped inverter and an LCL filter which is designed to reduced harmonics and meet the standards such as IEEE 519 and IEC 61000-3-6. The power conditioning control scheme comprises voltage and current regulators to provide a good power factor and satisfy synchronization requirements with the grid. The frequency and phase are synchronized with those of the grid through a phase-locked-loop. The modelling and simulation are performed using Matlab/Simulink. The results show good performance of the proposed microgrid as well as the inverter design and control approach with a low total harmonic distortion of about $0.35 \%$ for the voltage and $0.19 \%$ for the current.
\end{abstract}

Keywords: Fuel Cell; Grid-Connected Multi-Level Inverter; Grid Synchronization; Passive Filter; VSI Control.

\section{Introduction}

Energy sources dependent on oil, natural gas and coal have demonstrated their capacities to permit economic development. However, with the fast exhaustion of fossil fuels, the expansion of the world energy demand and concerns over global warming, new energy systems dependent on renewable and other sustainable energy are gaining more interests. It is now a reality that future development in the energy sector is basically founded on the utilization of renewable and sustainable energy sources. In this way, moving to sustainable energy sources can empower to meet the double targets of diminishing greenhouse gas emissions, by that overcoming extreme weather conditions and ensuring reliable and cost-effective energy supply. Fuel cells are one of the advanced clean energy technologies and have demonstrated their ability to be a decent substitute to address the above-mentioned concerns. They are viewed as reliable and one of the most efficient technologies as their efficiency ranges between 40 and $60 \%$ while the efficiencies of other technologies are lower [1]. A common fuel cell system utilizes hydrogen to produce power with heat and pure water as the by-product [2]. Various types of fuel cells can be found in market including proton exchange membrane fuel cell (PEMFC) alkaline fuel cell (AFC), phosphoric acid fuel cell (PAFC), molten carbonate fuel (MCFC) cell, direct methanol fuel cell (DMFC), solid oxide fuel cell (SOFC), however, proton exchange membrane fuel cell (PEMFC) is the most appealing in view of its low operating temperature, low noise, high efficiency and low pollution. As of now, PEMFC technologies have grown such that it is possible to acquire a megawatt power module and connected it to the utility grid [3].

In general, PEMFC produces DC (direct current) power at a low voltage level. To acquire high power fuel cell systems, PEMFCs are associated in series and parallel to form multi-stacks fuel cell systems. For grid-tied operation mode, a power converter is required to condition the generated DC voltage and converts it to AC power with synchronized frequency and phases. This power converter can also permit the control of power quality and power supply. A power converter can be either a DC-to-DC converter or an inverter or both depending on the load. A common power converter needs to comply with the following specifications [4]:

High gain,

Small current ripple,

High efficiency and low costs.

Several ways exist to connect fuel cell systems into an AC utility grid using power converters, the most popular configurations are [5]: Centralized configuration, 
String configuration

Multi-string configuration

Centralized and string configurations (Fig. 1A and 1B) can provide the similar output power without a converter to boost the output voltage of the fuel cell. However, their principal issue is the low output voltage in case it is fully loaded and high voltage when there is no-load [6]. A solution to overcome this issue is to connect a DC-to-DC voltage regulator before the inverter (Fig. 1C) to keep the voltage constant at the DC-link, thereby suppressing the dependence of the inverter input voltage on the load current. In such a case, a DC-to-DC boost converter can be associated to each fuel cell and the steady DC outputs of these converters can be connected in parallel. The benefits of this configuration include:

Each fuel cell can be controlled independently with the DC-to-DC converter;

The stack can be disconnected from the system for maintenance or replaced while the remainder of the system is kept operating;

The system's reliability can be improved alongside with fault-tolerant operations by including redundant fuel cell stacks with DC-to-DC converters;

Each subsystem can be designed independently and combined as required.

However, the capital cost involved is very.

The topology adopted in this study is centralized configuration (Fig. 1A). Different types of inverter ranging from low to high level can be used in centralized configuration depending on the power requirement. For low power and low voltage applications, the two-level inverter configuration is the most used topology whereas for high power and high voltage applications, multi-level inverter configuration is more suitable. Applications of multi-level inverters range from medium to high voltage and comprise power distribution, motor drives, etc. For a given application, the choice of appropriate multi-level topology and its control scheme are not defined and depend on various engineering compromises, however, the most developed multi-level inverter topologies include the Diode Clamped, the Flying Capacitor and the Cascade Full Bridge inverters.

Diode Clamped multilevel inverter is the most accepted topology; the concept behind this inverter is to use diodes to limit the power devices voltage stress. The voltage at each capacitor and each switch is Vdc. An n-level inverter requires (n-1) voltage sources, 2(n-1) switching devices and (n-1) (n-2) diodes. By enlarging the number of voltage levels, the output voltage quality is improved, and the voltage waveform is nearly sinusoidal. The voltage across each capacitor is $\mathrm{Vdc} / 2$ and each device voltage stress will be limited to one capacitor voltage level $\mathrm{Vdc} / 2$ through clamping diodes. The three-level diode clamped inverter is one of the most available topologies in the market; it is widely used in industrial applications in the range of 2.3 to $6.6 \mathrm{kV}$.


Fig. 1: Topologies for Grid-Connected Fuel Cell Systems: (A) Centralized Configuration, (B) String Configuration and (C) Multi-String Configuration. [7]

A common inverter generates harmonics as its output voltage or current is not a pure sine wave. In general, harmonics are caused by nonlinear loads, drawing non-sinusoidal current from sinusoidal voltage sources. These loads include power electronics converters, motor drives and electric arc furnaces. Loads including fluorescent lamps, computers, fax machines, photocopiers, laser printers, battery chargers, etc. are also sources of harmonics. These harmonics impact negatively on sensitive equipment above several kilowatts of the connected loads [8]. Standards such each IEEE 519 and IEC 61000-3-6 set the allowable harmonic distortion for both the current and the voltage in a power system based on the current level and the voltage level respectively. Conventional criteria used to reduce harmonics is the use of an input inductance while the output inductance of the power conversion devices serves as filters. However, due to the increase in the size of systems, realizing practical filters becomes difficult due to high cost and poor system dynamic response. An LCL filter is connected after the inverter to eliminate harmonics resulting from the inverter switching. In comparison with other filters such as an $\mathrm{L}$ and LC filters, an LCL filter has the benefit of achieving better attenuation capacity for complex harmonics and has better dynamic characteristics [9,10]. However, an LCL filter can cause instability problems because of its zero impedance which may create resonance for some frequencies. To overcome this issue, various damping techniques such as incorporating a physical passive element in series with the filter capacitor [11] have been proposed. Among these damping techniques, the technique using a passive element is simple and reliable, however, the passive element causes power loss and weakens the effect of the LCL filter which can be overcome by using an active damping technique [12]. Inverters can operate either in off-grid or grid-connected mode. When operating in grid-connection mode, the inverter output voltage and frequency should be the same as those of the grid. Hence, the current injected into the grid should be balanced, sinusoidal, and have a total harmonic distortion lower than 5\% [13]. To achieve these requirements, the control of the inverter plays a vital role and in such a case, the objective of the control action is to properly feed the extracted power to the grid. To obtain higher performance several control strategies for grid-connected inverters have been proposed, such as selective harmonics elimination pulse-width modulation (SHE-PWM), pulsewidth modulation (PWM) and optimized harmonics stepped pulse-width modulation (OHS-PWM) [14], however, this research focuses on 
the PWM control approach. The PWM control approach can be grouped into open loop and closed loop control systems; the open-loop PWM techniques are SPMW, space vector PWM, sigma-delta modulation, while closed loop current control methods. For grid-connected inverters, the closed loop control consists three major steps namely the outer loop control, inner loop control and synchronization. The outer control loop can be a DC-link voltage control or a power control loop, which generates the inner current references, on the other, the inner current loop regulates the injected currents, while the synchronization is achieved through a phase-locked-loop (PLL) which uses the grid to provide the correct phase and frequency.

This research aims to model and control a three-level diode clamped inverter for grid-connected megawatt fuel cell applications. The considered system includes a $1.54 \mathrm{MW} / 1400 \mathrm{~V}$ DC proton exchange membrane fuel cell stack, a $1.3 \mathrm{MW} / 600 \mathrm{~V}$ three-level diode clamped inverter and an LCL with a total voltage harmonic distortion of $0.5 \%$. The inverter control scheme comprises voltage and current regulators to provide a good power factor and satisfy synchronization requirements with the grid. The frequency and phase are synchronized with those of the grid through a phase-locked-loop. Modelling and simulation are performed using Matlab/Simulink.

The rest of the paper is organized as follows: Section 2 deals with the description and modelling of the grid -tied megawatt fuel cell system, Section 3 focuses on the results and discussion and the last Section gives the conclusion.

\section{Grid-tied megawatt fuel cell description and modelling}

\subsection{Description}

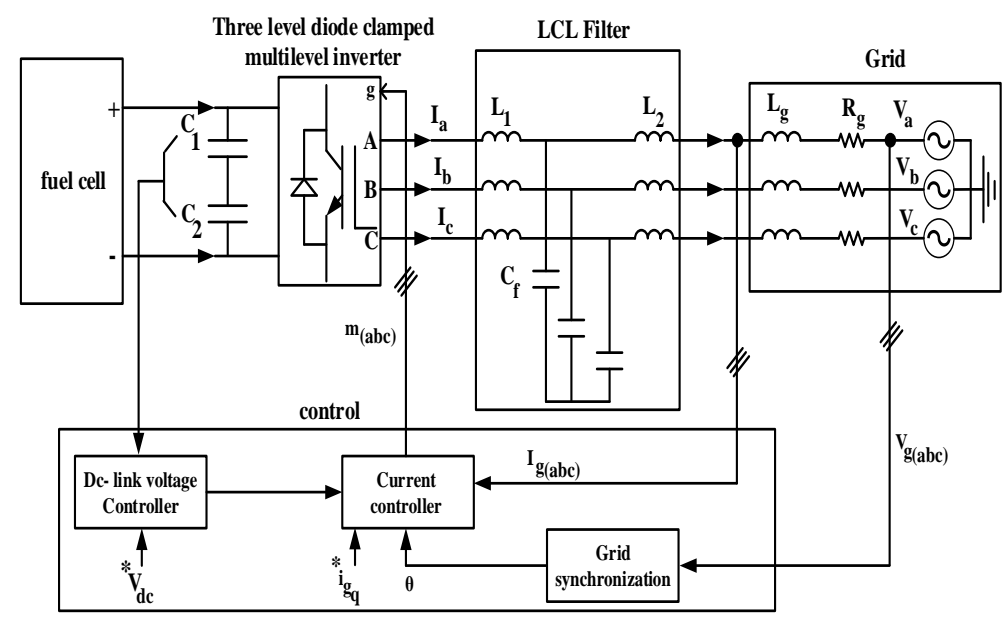

Fig. 2: Layout of Grid-Connected Megawatt Fuel Cell Stack.

The topology adopted in this study is the centralized configuration, whereby the megawatt proton exchange membrane fuel cell (PEMFC) stack is connected to the grid directly through the inverter without the use of DC-to-DC converters. As depicted in Fig.2, besides the megawatt PEMFC stack, the system includes a three-level diode clamped inverter and a power filter unit connecting the system to the grid. The megawatt stack is realized through series and parallel connection of individual PEMFC stacks. Each PEMFC stack generates $126 \mathrm{~kW}$ at $1400 \mathrm{Vdc}$. The overall power of the megawatt multi PEMFC stack fuel cell is $1.54 \mathrm{MW}$. A three-level diode clamped inverter converts the 1400 DC voltage of the fuel cell to AC to supply a local load and feed any excess into the utility grid depending on the generation conditions. To mitigate the effects of harmonics voltage and current, an LCL filter is interfaced between the inverter, the local load and the grid.

\subsection{Modelling}

\subsubsection{Modelling of PEMFC}

The output voltage of a PEMFC consists of four terms namely Nernst potential $E_{N e r n s t}$, activation potential $V_{\text {act }}$, concentration difference potential $V_{\text {con }}$ and $V_{\text {ohmic }}[15]$, [16],. This output voltage is expressed as follows:

$$
\begin{aligned}
& \mathrm{V}_{\mathrm{FC}}=\mathrm{E}_{\mathrm{Nernst}}-\mathrm{V}_{\text {act }}-\mathrm{V}_{\text {ohm }}-\mathrm{V}_{\mathrm{Con}} \\
& \mathrm{E}_{\mathrm{Nernst}}=1.229-0.8510^{-3}(\mathrm{~T}-298.15)+4.308510^{-5} \times \mathrm{T} \ln \left[\mathrm{P}_{\mathrm{H} 2} \frac{\mathrm{P}_{\mathrm{O}}^{0.5}}{\mathrm{P}_{\mathrm{H} 2 \mathrm{O}}}\right] \\
& \mathrm{V}_{\mathrm{act}}=-\left[\zeta_{1}+\zeta_{2} \mathrm{~T}+\zeta_{3} \mathrm{~T} \ln \left(\mathrm{C}_{\mathrm{O} 2}\right)+\zeta_{4} \mathrm{~T} \ln \left(\mathrm{i}_{\mathrm{FC}}\right)\right] \\
& \mathrm{C}_{\mathrm{O}_{2}}=\frac{\mathrm{P}_{\mathrm{O}_{2}}}{5.08 \times 10^{6} \exp (-498 / \mathrm{T})} \\
& \mathrm{L}_{\mathrm{ohm}}=\mathrm{i}_{\mathrm{FC}}\left(\mathrm{R}_{\mathrm{m}}+\mathrm{R}_{\mathrm{c}}\right) \\
& \mathrm{R}_{\mathrm{m}}=\frac{\rho_{\mathrm{m}} 1}{\mathrm{~A}} \\
& \rho_{\mathrm{m}}=\frac{\left(181.6\left[1+0.03\left(\frac{\mathrm{i} \mathrm{FC}}{\mathrm{A}}\right)+0.062\left(\frac{\mathrm{T}}{303}\right)^{2}\left(\frac{\mathrm{i} \mathrm{FC}}{\mathrm{A}}\right)^{2.5}\right]\right.}{\left(\left[\Psi-0.634-3\left(\frac{\mathrm{iFC}}{\mathrm{A}}\right)\right] \exp \left(\frac{4.18 \times(\mathrm{T}-303)}{\mathrm{T}}\right)\right)}
\end{aligned}
$$


$\mathrm{V}_{\text {conc }}=-\mathrm{B} \cdot \ln \left(1-\frac{\mathrm{J}}{\mathrm{J}_{\max }}\right)$

$\mathrm{J}=\frac{\mathrm{I}_{\mathrm{FC}}}{\mathrm{A}}$

The parameters, physical meaning with units and value used in the modelling of a PEMFC stack are given in Table 1 [17], while Table 2 shows the general characteristics of the obtained Megawatt fuel cell stack.

\begin{tabular}{lll} 
& \multicolumn{2}{c}{ Table 1: Single PEMFC Parameters } \\
\hline Parameter & $\begin{array}{l}\text { PEMFC stack } \\
\text { Physical meaning and units }\end{array}$ & Value \\
\hline $\mathrm{T}$ & Stack temperature ${ }^{\circ} \mathrm{K}$ & 338 \\
$\mathrm{~A}$ & Activation area cm ${ }^{2}$ & 50.6 \\
$\mathrm{~L}$ & Membrane thickness $\mu \mathrm{m}$ & $178(\mathrm{Nation} 117)$ \\
$\mathrm{P}_{\mathrm{H} 2}$ & Hydrogen pressure atm $(0.1 \mathrm{MPa})$ & $1 \mathrm{~atm}$ \\
$\mathrm{P}_{\mathrm{O} 2}$ & Oxygen pressure atm $(0.1 \mathrm{MPa})$ & $1 \mathrm{~atm}$ \\
$\mathrm{R}_{\mathrm{C}}$ & Membrane contact resistor $\Omega$ & 0.0003 \\
$\mathrm{~B}$ & Coefficient for computing $\mathrm{V}_{\text {con }}$ & 0.016 \\
$\zeta_{1}$ & Curve fitting parameter & -0.948 \\
$\zeta_{2}$ & Curve fitting parameter & 0.00312 \\
$\zeta_{3}$ & Curve fitting parameter & $7.6 \times 10^{-5}$ \\
$\zeta_{4}$ & Curve fitting parameter & $-1.93 \times 10^{-4}$ \\
$\Psi$ & Membrane moisture content & 23 \\
$\mathrm{I}_{\mathrm{L}}$ & Current density driven from PEMFC mA $/ \mathrm{cm}^{2}$ & 1500 \\
$\mathrm{C}_{\mathrm{O}_{2}}$ & $\mathrm{O}_{2}$ concentration at the cathode $/(\mathrm{mole} / \mathrm{cm} 3)$ & - \\
\hline
\end{tabular}

Table 2: Megawatt PEMFC Parameters

\begin{tabular}{|c|c|c|}
\hline \multirow{2}{*}{ Parameter } & \multicolumn{2}{|c|}{ Megawatt PEMFC stack } \\
\hline & Value & Unit \\
\hline Stack nominal power & 126000 & $\mathrm{~W}$ \\
\hline Stack maximum power & 134400 & W \\
\hline Fuel cell resistance & 8.2936 & Ohms $(\Omega)$ \\
\hline Nerst voltage of a stack $E_{n}$ & 1.1039 & $\mathrm{~V}$ \\
\hline \multicolumn{3}{|l|}{ Nominal utilization: } \\
\hline Hydrogen $\left(\mathrm{H}_{2}\right)$ & 98.47 & $\%$ \\
\hline Oxygen $\left(\mathrm{O}_{2}\right)$ & 99.99 & $\%$ \\
\hline \multicolumn{3}{|l|}{ Nominal consumption: } \\
\hline Fuel & 1259 & Slpm \\
\hline Air & 2985 & Slpm \\
\hline Exchange current $\left(i_{o}\right)$ & 12.8226 & A \\
\hline Exchange coefficient (alpha) & -0.38762 & - \\
\hline \multicolumn{3}{|l|}{ Fuel cell signal variation parameters: } \\
\hline Fuel cell composition (x_H2) & 99.56 & $\%$ \\
\hline Oxygen composition (y_O2) & 21 & $\%$ \\
\hline \multicolumn{3}{|l|}{ Fuel flow rate at nominal hydrogen utilization: } \\
\hline Nominal & 1056 & $1 \mathrm{pm}$ \\
\hline Maximum & 1970 & $1 \mathrm{pm}$ \\
\hline \multicolumn{3}{|l|}{ Air flow rate at nominal hydrogen utilization: } \\
\hline Nominal & 3700 & $1 \mathrm{pm}$ \\
\hline Maximum & 6907 & $1 \mathrm{pm}$ \\
\hline System temperature $(\mathrm{T})$ & 338 & Kelvin \\
\hline Fuel supply pressure $\left(\mathrm{P}_{\text {fuel }}\right)$ & 10.5 & bar \\
\hline Air supply pressure $\left(\mathrm{P}_{\text {air }}\right)$ & 1 & bar \\
\hline Number of cells & 2000 & - \\
\hline Nominal stack efficiency & 55 & $\%$ \\
\hline Number of stacks & 12 & \\
\hline Megawatt fuel cell voltage at $0 \mathrm{~A}$ & 2000 & V \\
\hline Megawatt fuel cell voltage at $1 \mathrm{~A}$ & 1800 & $\mathrm{~V}$ \\
\hline Megawatt stack nominal power & 1.4 & MW \\
\hline Megawatt stack nominal current & 1100 & A \\
\hline Megawatt fuel cell nominal operating point of the current & 90 & A \\
\hline Megawatt fuel cell nominal operating point of the voltage & 1400 & $\mathrm{~V}$ \\
\hline Megawatt fuel cell maximum operating point of the current & 168 & A \\
\hline Megawatt fuel cell Maximum operating point of the voltage & 800 & V \\
\hline
\end{tabular}

\subsubsection{Modelling of three-level diode clamped inverter}

A typical three-level diode clamped inverter is composed of twelve switches and six clamping diodes as shown in Fig. 3. The DC-link capacitor is separated into two parts, and the midpoint between the upper and lower parts is known as the neutral point. The six diodes called clamping diodes connect the output of each leg of the inverter to the neutral point. The three-level diode clamped inverter is based on a series connection of four switches in each leg. In comparison with a two-level inverter, the rated voltage of the used switch can be reduced by half, making it appropriate for a high voltage and large capacity system. 




Fig. 3: Topology of Three-Level Inverter. [18].

The switching operation of a three-level diode clamped inverter is shown in Table 3, whereby if the switches $S_{\mathrm{a} 1}$ and $\mathrm{S}_{\mathrm{a} 2}$ are turned on and $\mathrm{S}_{\mathrm{a} 3}$ and $\mathrm{S}_{\mathrm{a} 4}$ are off, the output voltage is $+\mathrm{V}_{\mathrm{dc}} / 2$. On the contrary, the output voltage is $-\mathrm{V}_{\mathrm{dc}} / 2$. On the other hand, if $\mathrm{S}_{\mathrm{a} 1}$ and $\mathrm{S}_{\mathrm{a} 4}$ are off and $\mathrm{S}_{\mathrm{a} 2}$ and $\mathrm{S}_{\mathrm{a} 3}$ are on, the output voltage is zero [4], [19].

Table 3: Switching States of A Three-Level Diode Clamped Inverter

\begin{tabular}{lllll}
\hline \multirow{2}{*}{ Switching state } & & \multicolumn{2}{l}{ Switching device state } & \multirow{2}{*}{ Out pole voltage $\mathrm{V}_{\mathrm{xn}}($ with $\mathrm{x}=\mathrm{a}, \mathrm{b}, \mathrm{c}$ and $\mathrm{n}=$ neutral) } \\
\hline $\mathrm{P}$ & $\mathrm{S}_{\mathrm{a} 1}$ & $\mathrm{~S}_{\mathrm{a} 2}$ & $\mathrm{~S}_{\mathrm{a} 3}$ & \\
$\mathrm{O}$ & $\mathrm{ON}$ & $\mathrm{ON}$ & $\mathrm{OFF}$ & $+\mathrm{V}_{\mathrm{dc}} / 2$ \\
$\mathrm{~N}$ & $\mathrm{OFF}$ & $\mathrm{ON}$ & $\mathrm{OFF}$ & 0 \\
\hline
\end{tabular}

The switching state of each leg can be expressed as $\mathrm{P}, \mathrm{N}$ and $\mathrm{O}$. Hence, it is possible to represent the three-leg output voltage utilizing the switching states of the three legs. In total, there are 27 switching states that can be represented by the three-leg output voltage, and these 27 switching states can be expressed as vectors as shown in Fig. 4.

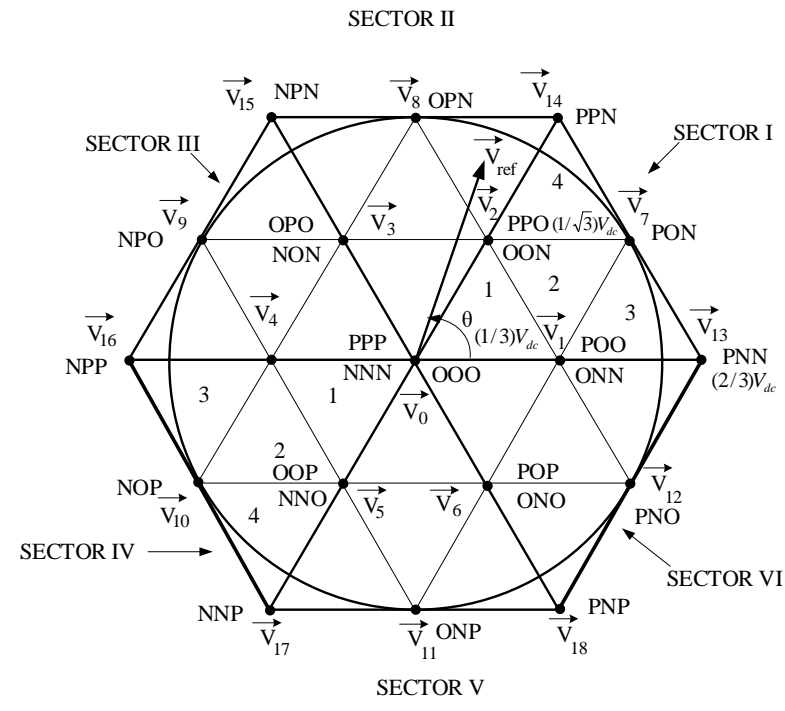

Fig. 4: Voltage Vector of Three-Level Inverter. [20].

The voltage vector diagram of a three-level inverter is divided into six sectors (Fig.4). Each of these sectors can be separated into four parts, which are expressed as regions $1-4$. In the space vector pulse-width modulation (PWM) method, the command voltage vector is obtained from the output voltage of the three-level converter.

The command voltage vector can be expressed using the magnitude $\left(\mathrm{V}_{\text {ref }}\right)$ and phase $(\theta)$ as shown in the equation (10).

$\overrightarrow{\mathrm{V}}_{\text {ref }}=\mathrm{V}_{\text {ref }} \mathrm{e}^{\mathrm{j} \theta}$

By considering only one sector (Sector I), the equations of voltage vectors $V_{1}, V_{2}$, and $V_{7}$ are expressed as follows:

$\overrightarrow{\mathrm{V}_{1}}=\frac{1}{3} \mathrm{~V}_{\mathrm{dc}}$

$\overrightarrow{\mathrm{V}_{2}}=\frac{1}{3} \mathrm{~V}_{\mathrm{dc}} \mathrm{e}^{\mathrm{j} \pi / 3}$

$\overrightarrow{\mathrm{V}_{7}}=\frac{\sqrt{3}}{3} \mathrm{~V}_{\mathrm{dc}} \mathrm{e}^{\mathrm{j} \pi / 6}$ 
The effective time of the selected valid vectors is determined so that the average output voltage during a switching period ( $\left.T_{\mathrm{S}}\right)$ becomes equal to the command voltage vector $\left(\mathrm{V}^{*}\right)[4]$. Therefore, the following equations must be satisfied:

$\overrightarrow{\mathrm{V}_{\mathrm{ref}}} \mathrm{T}_{\mathrm{s}}=\overrightarrow{\mathrm{V}_{1}} \mathrm{~T}_{1}+\overrightarrow{\mathrm{V}_{2}} \mathrm{~T}_{2}+\overrightarrow{\mathrm{V}_{7}} \mathrm{~T}_{7}$

$\mathrm{T}_{\mathrm{s}}=\mathrm{T}_{1}+\mathrm{T}_{2}+\mathrm{T}_{7}$

Where $\mathrm{T}_{1}, \mathrm{~T}_{2}$, and $\mathrm{T}_{7}$ are the effective switching time of the selected voltage vector $\mathrm{V}_{1}, \mathrm{~V}_{2}$ and $\mathrm{V}_{7}$ respectively. By combining (10), (11) and (12), the following equation is obtained:

$\mathrm{V}_{\text {ref }} \mathrm{e}^{\mathrm{j} \theta} \mathrm{T}_{\mathrm{s}}=\frac{1}{3} \mathrm{~V}_{\mathrm{dc}} \mathrm{T}_{1}+\frac{\sqrt{3}}{3} \mathrm{~V}_{\mathrm{dc}} \mathrm{e}^{\mathrm{j} \pi / 6} \mathrm{~T}_{2}+\frac{1}{3} \mathrm{~V}_{\mathrm{dc}} \mathrm{e}^{\mathrm{j} \pi / 3} \mathrm{~T}_{7}$

The obtained parameters of the inverter are given in Table 4

Table 4: Inverter Parameters

\begin{tabular}{lc}
\hline Parameters & Value \\
\hline DC link voltage $\left(\mathrm{V}_{\mathrm{DC}}\right)$ & $1400 \mathrm{~V}$ \\
Output power of the inverter & $1.3 \mathrm{MW}$ \\
Line-to-line RMS voltage $\left(\mathrm{V}_{\mathrm{LL}}\right)$ & $600 \mathrm{~V}$ \\
Phase voltage $\left(\mathrm{V}_{\mathrm{PH}}\right)$ & $346 \mathrm{~V}$ \\
Nominal current $\left(\mathrm{I}_{\mathrm{RMS}}\right)$ & $1200 \mathrm{~A}$ \\
Power factor $\left(\mathrm{P}_{\mathrm{f}}\right)$ & 0.95 \\
Peak-to-peak current $\left(\mathrm{I}_{\mathrm{Max}}\right)$ & $1630.22 \mathrm{~A}$ \\
Switching frequency $\left(\mathrm{f}_{\mathrm{sw}}\right)$ & $2000 \mathrm{~Hz}$ \\
Grid frequency $\left(\mathrm{f}_{\mathrm{g}}\right)$ & $50 \mathrm{~Hz}$ \\
Modulation range $\left(\mathrm{m}_{\mathrm{a}}\right)$ & 0.7 \\
Attenuation factor $\left(\mathrm{K}_{\mathrm{a}}\right)$ & $20 \%$ \\
Maximal power factor variation acceptable by grid & $5 \%$ \\
Inverter configuration & Three-phase \\
Phase-to-ground inverter voltage before filter & $930 \mathrm{~V}$ \\
Output current before the filter & $1200 \mathrm{~A}$ \\
\hline
\end{tabular}

\subsubsection{Modelling of LCL filter}

The role of the LCL filter is to reduce high-order harmonics from the output of the inverter, however, poor design can result to an increased total harmonic distortion. Fig. 5 displays a typical model of an LCL filter, where $\mathrm{L}_{\mathrm{i}}$ is the inverter side inductor, $\mathrm{L}_{\mathrm{g}}$ is the grid side inductor, $R_{i}$ and $R_{g}$ are inductors series resistance, $C_{f}$ is the filter capacitance, $R_{f}$ is the damping resistance, $V_{i}$ is the inverter input voltage, $V_{g}$ is the output voltage of the system ( grid voltage ), $I_{i}$ is the inverter output current, $I_{g}$ is the grid current and $I_{c}$ is the capacitor current.

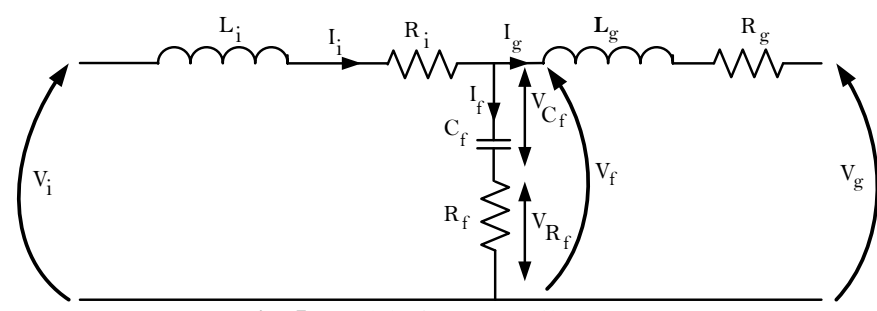

Fig. 5: Model of an LCL Filter. [21].

The filter transfer function can be expressed as:

$\mathrm{H}_{\mathrm{LCL}}=\frac{\mathrm{I}_{\mathrm{g}}}{\mathrm{V}_{\mathrm{i}}}$

Where the grid voltage is assumed to be an ideal voltage source capable of damping all the harmonic frequencies. If $V_{\mathrm{g}}=0$, the transfer function is expressed as follows [22]:

$\mathrm{H}_{\mathrm{LCL}}=\frac{1}{\mathrm{~L}_{\mathrm{i}} \mathrm{L}_{\mathrm{g}} \mathrm{C}_{\mathrm{f}} \mathrm{S}^{3}+\left(\mathrm{L}_{\mathrm{i}}+\mathrm{L}_{\mathrm{g}}\right) \mathrm{S}}$

By including the damping resistance, the transfer function is, furthermore, expressed as [22]:

$\mathrm{Hd}_{\mathrm{LCL}}=\frac{\mathrm{C}_{\mathrm{f}} \mathrm{R}_{\mathrm{d}} \mathrm{S}+1}{\mathrm{~L}_{\mathrm{i}} \mathrm{C}_{\mathrm{f}} \mathrm{S}^{3}+\mathrm{C}_{\mathrm{f}}\left(\mathrm{L}_{\mathrm{i}}+\mathrm{L}_{\mathrm{g}}\right) \mathrm{R}_{\mathrm{d}} \mathrm{S}^{2}+\left(\mathrm{L}_{\mathrm{i}}+\mathrm{L}_{\mathrm{g}}\right) \mathrm{S}}$

Several characteristics are taken into account in the design of an LCL filter, such as filter size, current ripples and switching ripple attenuation. The reactive power demands can result to a resonance of the capacitor interacting with the grid. Hence, passive or active damping are added by including a resistor in series with the capacitor. In this study, the passive damping option is adopted, however, active damping can also be considered [23-25]. The base impedance and base capacitance $Z_{b}$ and $C_{b}$ are given by (18) and (19) as follows:

$\mathrm{Z}_{\mathrm{b}}=\frac{\mathrm{U}_{\mathrm{n}}^{2}}{\mathrm{P}_{\mathrm{n}}}$ 
$\mathrm{C}_{\mathrm{b}}=\frac{1}{\omega_{\mathrm{g}} \mathrm{Z}_{\mathrm{b}}}$

Where is $P_{n}$ is the output power of the inverter, $U_{n}$ the line-to-line voltage and $\omega_{g}$ the system's frequency.

The filter capacitance $\mathrm{C}_{\mathrm{f}}$ serving as a sink for harmonics with high frequency is calculated by setting a percentage of not more than $5 \%$ of the base capacitance $\mathrm{C}_{\mathrm{b}}$ [26]. This study considers that percentage as equal to 5\%. The filter capacitance is given by (20) as follows:

$\mathrm{C}_{\mathrm{f}}=\mathrm{X} \cdot \mathrm{C}_{\mathrm{b}}$

The maximum current ripple at the output of the inverter is given by (21) [27]:

$\Delta \mathrm{I}_{\mathrm{Lmax}}=\frac{2 \mathrm{~V}_{\mathrm{DC}}}{3 \mathrm{~L}_{\mathrm{i}}}(1-\mathrm{m}) \mathrm{mT}_{\mathrm{SW}}$

Where $\mathrm{V}_{\mathrm{DC}}$ is the DC link voltage, $\mathrm{T}_{\mathrm{SW}}=\frac{1}{\mathrm{f}_{\mathrm{SW}}}$ is the period, and $(\mathrm{m})$ is the inverter modulation often between 0 and 1 . In this study, m is selected equal to 0.57 . With $\mathrm{m}=0.57,(21)$ becomes $[28]$ :

$\Delta \mathrm{I}_{\mathrm{Lmax}}=\frac{0.49 * \mathrm{~V}_{\mathrm{DC}}}{3 \mathrm{~L}_{\mathrm{i}} \mathrm{f}_{\mathrm{SW}}}$

Inverter side current ripple $(\Delta \mathrm{I})$ percentage is limited between 10 to $25 \%$ of the peak output current ( $\left.\mathrm{I}_{\text {max }}\right)$, thus, $\Delta \mathrm{I}_{\text {Lmax }}$ can be expressed as:

$\Delta \mathrm{I}_{\mathrm{Lmax}}=(1 \%-5 \%) * \mathrm{I}_{\max }$

This study considered $\Delta \mathrm{I}_{\mathrm{Lmax}}$ as $1 \%$, hence, $\Delta \mathrm{I}_{\mathrm{Lmax}}=0.01 \mathrm{I}_{\max }$.

Where

$\mathrm{I}_{\max }=\frac{\mathrm{P}_{\mathrm{n}} \sqrt{2}}{3 \mathrm{~V}_{\mathrm{ph}}}$

From (23), Li can be expressed as:

$\mathrm{L}_{\mathrm{i}}=\frac{0.49 \mathrm{~V}_{\mathrm{DC}}}{3 \Delta \mathrm{I}_{\mathrm{Lmax}} * \mathrm{f}_{\mathrm{SW}}}$

Where $f_{W S}$ is the switching frequency

The LCL filter must reduce the current ripple up to $20 \%$, resulting in a ripple value of about $5 \%$ of the output current [27,29]. Equation (26) gives the harmonic current generated by the inverter with the one from the grid as:

$\frac{\mathrm{I}_{\mathrm{g}}(\mathrm{h})}{\mathrm{I}_{\mathrm{i}}(\mathrm{h})}=\frac{1}{\left|1+\mathrm{r}\left[1-\mathrm{L}_{\mathrm{i}} \mathrm{C}_{\mathrm{b}} \omega_{\mathrm{sw}}^{2} \mathrm{X}\right]\right|} \mathrm{K}_{\mathrm{a}}$

Where, $\mathrm{Ka}$ is the desired attenuation and $\mathrm{r}$ is the ratio between the inductance at the inverter side and the grid side. This ratio is given as:

$\mathrm{L}_{\mathrm{i}}=\mathrm{rL}_{\mathrm{g}}$

The grid inductance is expressed by (28) as follows:

$\mathrm{L}_{\mathrm{g}}=\frac{\sqrt{\frac{1}{\mathrm{~K}_{\mathrm{a}}^{2}}}+1}{\mathrm{C}_{\mathrm{f}} \omega_{\mathrm{SW}}^{2}}$

The resonant frequency $\omega_{\text {res }}$ and the damping ratio $(\zeta)$ of the LCL-filter are obtained as [29]:

$\omega_{\text {res }}=\sqrt{\frac{\mathrm{L}_{\mathrm{i}}+\mathrm{L}_{\mathrm{g}}}{\mathrm{L}_{\mathrm{i}} \mathrm{L}_{\mathrm{g}} \mathrm{C}_{\mathrm{f}}}}$

$\zeta=\frac{\mathrm{C}_{\mathrm{f}} \omega_{\mathrm{res}} \mathrm{R}_{\mathrm{d}}}{2}$

The resonant frequency for the LCL filter can be determined as:

$\mathrm{f}_{\text {res }}=\frac{1}{2 \pi} \sqrt{\frac{\mathrm{L}_{\mathrm{i}}+\mathrm{L}_{\mathrm{g}}}{\mathrm{L}_{\mathrm{i}} \mathrm{L}_{\mathrm{g}} \mathrm{C}_{\mathrm{f}}}}$

This frequency is often set to satisfy (32) given as:

$10 \mathrm{f}_{\mathrm{g}}<\mathrm{f}_{\mathrm{res}}<0.5 \mathrm{f}_{\mathrm{SW}}$

In case (32) is not satisfied, parameters must be recalculated, and the value of the damping resistor can be calculated as:

$\mathrm{R}_{\mathrm{f}}=\frac{1}{3 \omega_{\text {res }} \mathrm{C}_{\mathrm{f}}}$ 
Table 5 gives the filter parameters obtained.

Table 5: LCL Filter Design Parameters

\begin{tabular}{ll}
\hline Parameters & LCL filter design value \\
\hline Inverter side inductor $\left(\mathrm{L}_{\mathrm{i}}\right)$ & $0.9 \mathrm{mH}$ \\
Grid side inductor $\left(\mathrm{L}_{\mathrm{g}}\right)$ & $0.072 \mathrm{mH}$ \\
Capacitor filter $\left(\mathrm{C}_{\mathrm{f}}\right)$ & $531 \mu \mathrm{F}$ \\
Damping resistance $\left(\mathrm{R}_{\mathrm{f}}\right)$ & $0.118 \Omega$ \\
Resonant frequency $\left(\mathrm{f}_{\text {res }}\right)$ & $845 \mathrm{~Hz}$ \\
Inductors resistances $\left(\mathrm{R}_{\mathrm{i}}=\mathrm{R}_{\mathrm{g}}\right)$ & $0.00761 \Omega$ \\
Sampling frequency $\left(\mathrm{f}_{\mathrm{s}}\right)$ & $10000 \mathrm{~Hz}$ \\
Output power of the inverter $\left(\mathrm{P}_{\mathrm{n}}\right)$ & $1.3 \mathrm{MW}$ \\
Line-to-line RMS voltage $\left(\mathrm{U}_{\mathrm{n}}\right)$ & $600 \mathrm{~V}$ \\
\hline
\end{tabular}

\subsubsection{Modelling inverter control}

Outer control loop

Fig. 6 shows the outer control loop; the DC-link voltage is regulated to control the power of the inverter using an outer loop control. This voltage regulation provides desired power transfer. DC voltage controller provides reference current id* for the inner controller. The current reference $\mathrm{I}_{\mathrm{q}}^{*}$ is set to zero for unity power factor [30].

The DC-link voltage is kept constant, especially, in case of double-stage configurations where the DC-link voltage is controlled at a desired level. To guarantee an appropriate power injection to the grid, the DC-link voltage must be at least higher than the grid peak voltage.

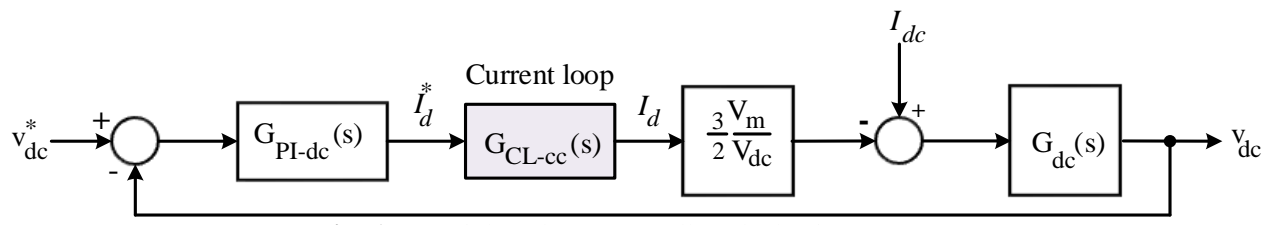

Fig. 6: DC-Link Voltage Controller Block Diagram. [31]

The energy stored in the dc-link capacitor is expressed as follows:

$\mathrm{E}_{\mathrm{DC}-\text { link }}=\frac{1}{2} \mathrm{C}_{\mathrm{DC} \text {-link }} \mathrm{V}_{\mathrm{DC}}^{2}$

Where $\mathrm{C}_{\mathrm{DC} \text {-link }}$ is the capacitance of the DC-link capacitor and $\mathrm{V}_{\mathrm{dc}-\text { link }}$ is the voltage across the DC-link capacitor. The total voltage across DC-link capacitor should be greater than $V_{D C-m i n}=\frac{2 \sqrt{2}}{\sqrt{3}} V_{L L}$ to obtain $V_{L L}$ at output of the inverter. DC voltage controller consists of PI controller to keep the $\mathrm{V}_{\mathrm{DC}}$ equal to $\mathrm{V}_{\text {ref }}$ [32]. The response time of outer voltage control is slow as compare to current controllers. The bandwidth of voltage controller is set between 0 to $20 \mathrm{~Hz}$. The calculated PI controller parameters $\mathrm{K}_{\mathrm{pv}}$ and $\mathrm{K}_{\mathrm{iv}}$ of voltage controller are given in Table 6.

Table 6: Outer Control Loop Parameters

\begin{tabular}{lll}
\hline Parameter & Value \\
\hline DC-link capacitor $\left(\mathrm{C}_{\mathrm{DC}}\right)$ & $50000 \mu \mathrm{F}$ \\
Proportional gain of controller $\left(\mathrm{K}_{\mathrm{pv}}\right)$ & 133.5 \\
Integral gain of controller $\left(\mathrm{K}_{\mathrm{iv}}\right)$ & $303,409.1$ \\
\hline
\end{tabular}

Inner control loop

The inner control loop (Fig. 7) takes the error between reference currents generated by the outer control loop and measured currents. The error is fed into the PI controller. The inner control loop must be designed such that it has high bandwidth to give fast response [33]. The transfer function of inner control loop is expressed in (35) and the parameters of the controller are given in Table 7.

$F(S)=\frac{1}{T_{s} s\left(T_{s} s+1\right)+1}$

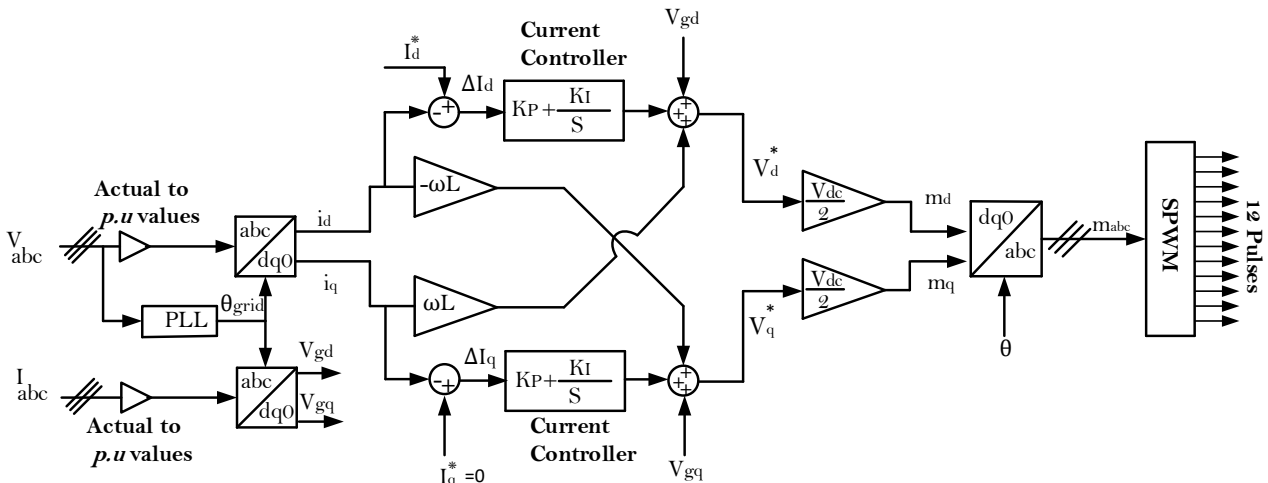

Fig. 7: Inner Control Loop. [5]. 
The output of the inner control loop (md and $\mathrm{mq}$ ) are transformed from dqo frame to abc to obtain the modulation which is fed into the PWM generator to produce the sinusoidal pulse width modulation signal (SPWM) then drive then inverter. For the three-level inverter, twelve pulses are required.

Table 7: Inner Control Loop Parameters

\begin{tabular}{ll}
\hline Parameter & Value \\
\hline Proportional gain of controller $\left(\mathrm{K}_{\mathrm{pc}}\right)$ & 3.24 \\
Integral gain of controller $\left(\mathrm{K}_{\mathrm{ic}}\right)$ & 50.625 \\
\hline
\end{tabular}

Grid synchronization

Various synchronization techniques have been reported in the literature, among which the most commonly employed technique is based on the phase-locked loop (PLL) method. Compared to other synchronization techniques, the PLL can deliver rapid and exact synchronization information with a high degree of immunity and insensitivity to disturbances, harmonics, unbalances, sags/swells, notches and other types of distortions in the input signal. Fig.8 shows a typical diagram of PLL. The injected output current of the converter must be synchronized with utility voltage [34]. Hence, the synchronization control of extracting angle of grid voltage plays an essential role in grid-connected inverter. The closed-loop transfer function of the PLL is given as follows:

$\mathrm{G}_{\mathrm{CL}-\mathrm{PLL}}(\mathrm{S})=\frac{\theta^{*}}{\theta}=\frac{\mathrm{K}_{1} \mathrm{~s}+\mathrm{K}_{2}}{\mathrm{~S}^{2}+\mathrm{K}_{1} \mathrm{~s}+\mathrm{K}_{2}}$

Where $\mathrm{K}_{1}$ and $\mathrm{K}_{2}$ are respectively the proportional and integral gain of the PI-based loop filter given in Table 8 .



Fig. 8: PLL Block Diagram. [35].

Table 8: PLL Based Loop Filter Parameters

\begin{tabular}{ll}
\hline Parameter & Value \\
\hline Proportional gain of controller $\left(\mathrm{K}_{1}\right)$ & 9.7 \\
Integral gain of controller $\left(\mathrm{K}_{2}\right)$ & 22045.45 \\
\hline
\end{tabular}

\section{Results and discussion}

The system described in section 2.1 was simulated using Matlab/Simulink software for a duration of 2.5 seconds to assess its performance based on parameters provided in Tables 4, 5,6,7 and 8. The megawatt fuel cell system was considered to operate in grid-tied mode. Furthermore, it was assumed that during the simulation, the hydrogen and oxygen composition, system temperature, hydrogen and oxygen pressure were unchanged.

The results from the simulation are presented in two parts namely the DC and AC parts. The DC side comprises the voltage, current and power generated by the megawatt stack then fed into the DC link, while the AC side consists of the output characteristics of the inverter, filter and the control.

The DC link voltage is displayed in Fig. 9; this voltage has some overshoot at the beginning of the simulation, subsequently gets to the stable value of $1400 \mathrm{~V}$ which is equal to the reference DC link voltage. The voltage has a rising time of about 5 milliseconds corresponding to the time needed for the voltage to rise from 0 to $100 \%$ of its final value. Additionally, the overshoot and undershoot of the voltage at the beginning of the simulation are $115.864 \%$ and $1.939 \%$ respectively before getting to its stable value. Similarly, the DC current presents an overshoot and undershoot at the beginning of the simulation are $1.970 \%$ and $68.052 \%$ respectively. On the other hand, the power response, it has a rising time of about 22.437 milliseconds, while the overshoot and undershoot of the voltage at the beginning of the simulation are $11.741 \%$ and $3.217 \%$ respectively, before getting to its stable value. 



Fig. 9: DC-Link Voltage.

The AC voltage is a three-level signal with the line to line value swinging between -VDC link to +VDC link as depicted in Fig. 10. This $\mathrm{AC}$ voltage is obtained at the output of the inverter without a filtering device. Its peak to peak value is about $2800 \mathrm{~V}$, hence, the maximum and minimum values are $+1400 \mathrm{~V}$ and $-1400 \mathrm{~V}$ respectively (see Fig. 10), while the RMS voltage is about $938 \mathrm{~V}$. The signal shown is in the form of pulses with varying widths according to the amplitude of the reference sine wave. The fundamental frequency of this signal is equal to that of the grid frequency, which is $50 \mathrm{~Hz}$.

The rise time of the phase to phase voltage is about 3.841 milliseconds, while the fall time is 3.971 milliseconds. Additionally, the overshoot and undershoot of the voltage at the beginning of the simulation are $0.49 \%$ and $25.347 \%$ respectively.

The phase-to-phase voltage of the three-level inverter shown in Fig. 10 is subjected to harmonics caused by the switching of power electronics devices in the inverter. These harmonics negatively impact on the system and can cause problems such as low efficiency, poor power factor, transient, etc. Standards such each IEEE 519 and IEC 61000-3-6 define the allowable harmonic distortion for both the current and the voltage in a typical power system based on the current level and the voltage level respectively. The allowable voltage total harmonic distortion is defined in terms of voltage level, while the current total demand distortion limit is expressed as function of the voltage level and the ratio of the short circuit current to the rated load current. IEEE 519-2014 defines the total harmonic distortion as the ratio of the root mean square of the harmonic content, considering harmonic components up to the 50th order and specifically excluding inter harmonics, expressed as a percent of the fundamental.

On the other hand, the total demand distortion is the ratio of the root mean square of the harmonic content, considering harmonic components up to the 50th order and specifically excluding inter harmonics.

The phase-to-phase voltage total harmonic distortion is depicted in Fig. 11; its value is around $44.99 \%$ for frequencies up to $5 \mathrm{kHz}$ when the fundamental is $50 \mathrm{~Hz}$. This percentage is far above the limit as set by standards. With such a distortion, a load can be subjected to fast deterioration, furthermore, the lifespan of the fuel cell can also be shortened, hence, the filtering of the inverter voltage waveforms is required.

The phase-to-phase voltages $\mathrm{V}_{\mathrm{a}}, \mathrm{V}_{\mathrm{b}}$, and $\mathrm{V}_{\mathrm{c}}$ and the current $\mathrm{I}_{\mathrm{a}}, \mathrm{I}_{\mathrm{b}}$ and $\mathrm{I}_{\mathrm{c}}$ after the passage into the low-pass LCL filter are shown in Fig. 12 . As expected, magnitudes of the phase voltages are about $600 \mathrm{~V}$, while the magnitudes of the phase currents are around 1200A. The rise time of the phase to phase voltage is about 5.867 milliseconds, while the fall time is 5.866 milliseconds. Additionally, the overshoot and undershoot of the voltage at the beginning of the simulation are $0.206 \%$ and $1.985 \%$ respectively.

Similarly, the rise time of the phase current is about 5.856 milliseconds, while the fall time is 5.854 milliseconds. Additionally, the overshoot and undershoot of the voltage at the beginning of the simulation are $0.284 \%$ and $1.985 \%$ respectively. 


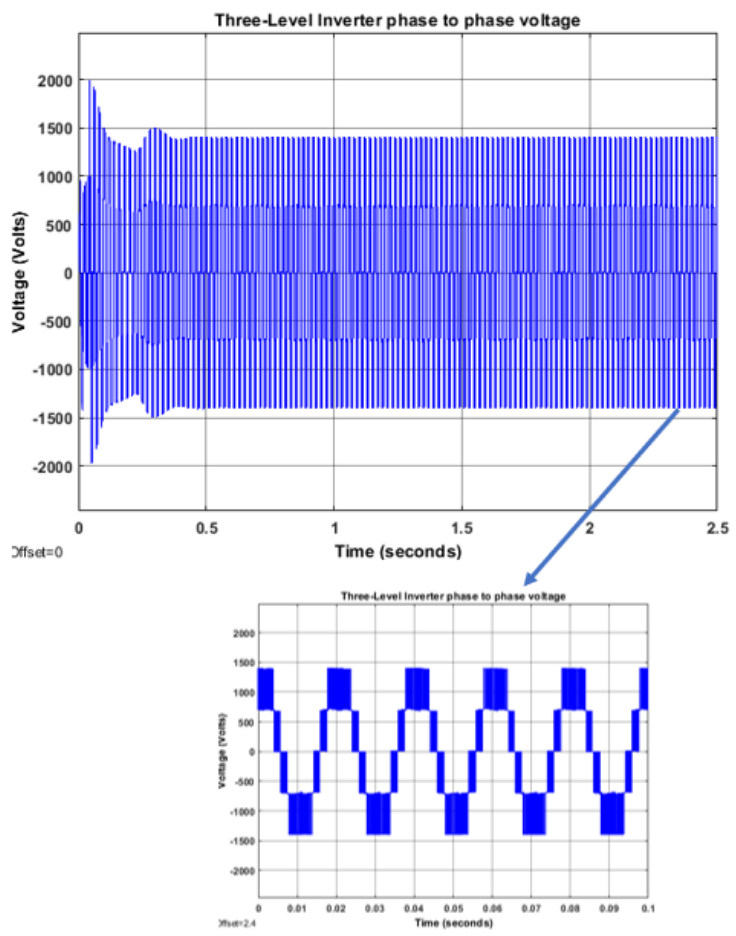

Fig. 10: Output Voltage of Three-Level Diode Clamped Inverter.

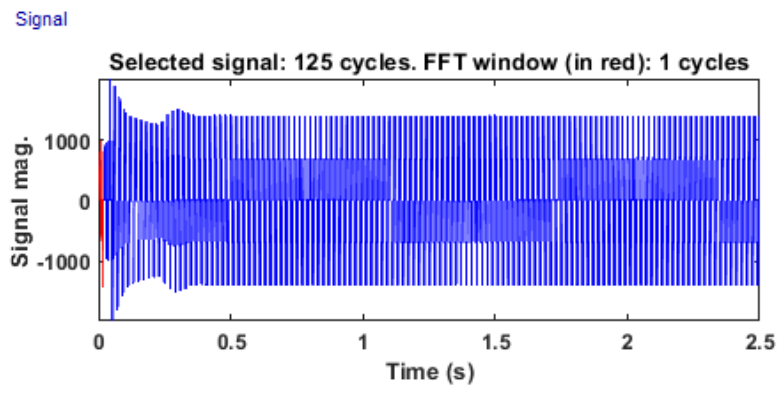

FFT analysis



Fig. 11: Phase-To-Phase Voltage Harmonic Distortion Before Filtering.

Fig. 13 and Fig. 14 depict the histograms of voltage total harmonic distortion and current harmonic distortion at the output of the LCL filter respectively. These charts are obtained for a 1.29 MW three-level inverter connected to the grid at $600 \mathrm{~V}$. The starting time for both harmonics voltage and current measurement is at zero second. With the designed filter, both harmonics are considerably reduced. The corresponding voltage total harmonic distortion is about $0.35 \%$ whereas the total harmonic distortion of the current is $0.19 \%$. The obtained values comply with the IEEE 519-2014 standards which states that the harmonic distortion limit for voltages less than $1 \mathrm{kV}$ is $8 \%$ [13]. On the other hand, IEEE 519-2014 defines the total demand distortion limit for voltages less than $69 \mathrm{kV}$ and currents greater than $1000 \mathrm{~A}$ as equal to $20 \%$ [13]. At a full load, both the total harmonic distortion and the total demand distortion are equal, hence, as the load was simulated at its full value, the corresponding total demand distortion is also equal to $0.19 \%$. This obtained value is conformed to the abovementioned standards. 

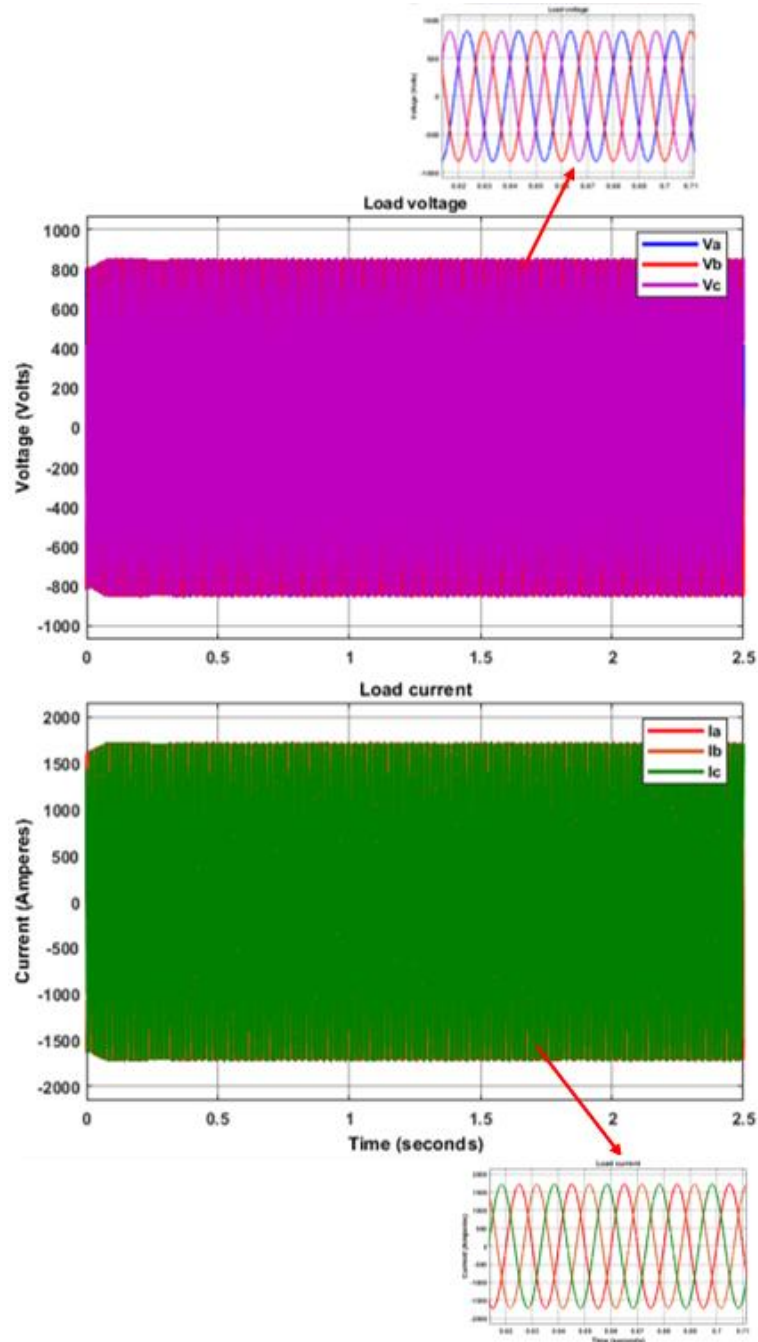

Fig. 12: Voltages and Currents After Filter.

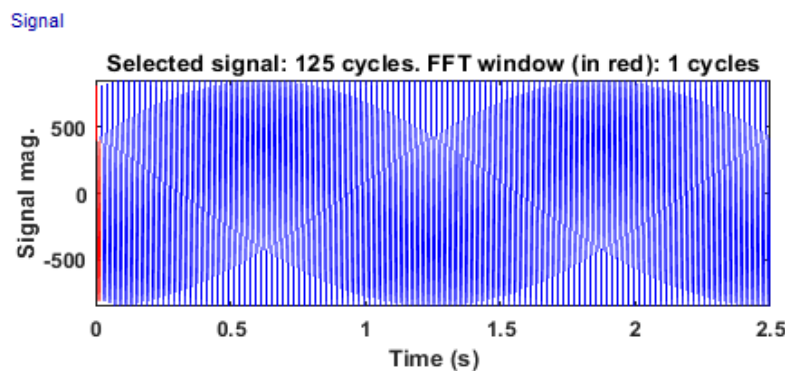

FFT analysis

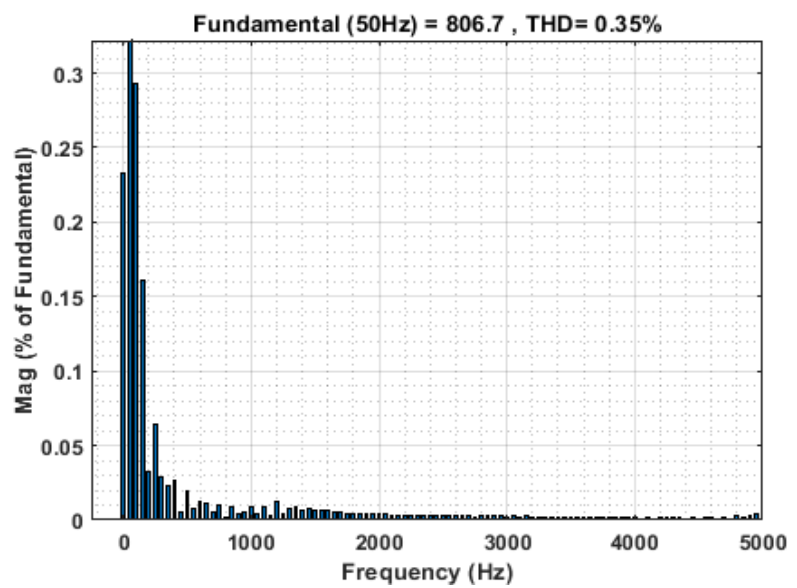

Fig. 13: Phase-To-Phase Voltage Harmonic Distortion After Filter.

The DC link voltage is displayed in Fig. 15a; this voltage is compared against the adopted reference voltage which is $1400 \mathrm{~V}$ to obtain the error for the design of the controller to generate the Id reference. The Id reference is then compared against the Id from the grid (Fig. 15b) 
to generate $V_{d}$ reference. On the other hand, $I_{q}$ reference is set to zero and compare against the grid $I_{q}$ to generate $V_{q}$ reference. Both $V_{d}$ and $\mathrm{V}_{\mathrm{q}}$ reference values are then modulated as $\mathrm{md}$ and $\mathrm{m}_{\mathrm{q}}$, then transformed to abc frame to generate the SPWM to drive the inverter.
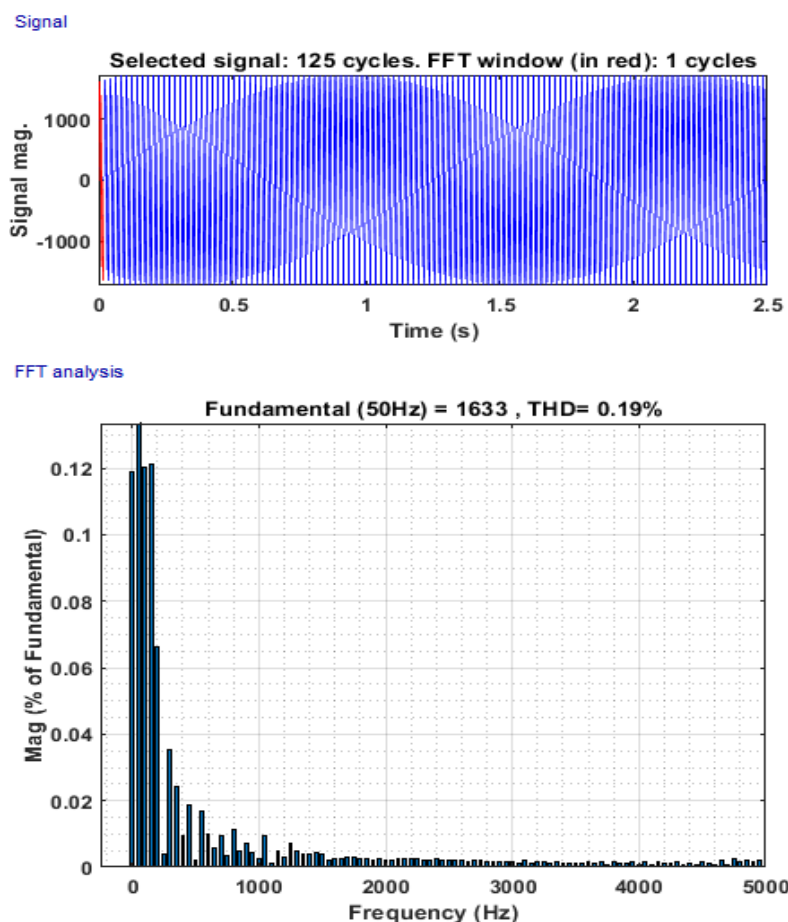

Fig. 14: Phase Current Harmonic Distortion after Filter.

(A)

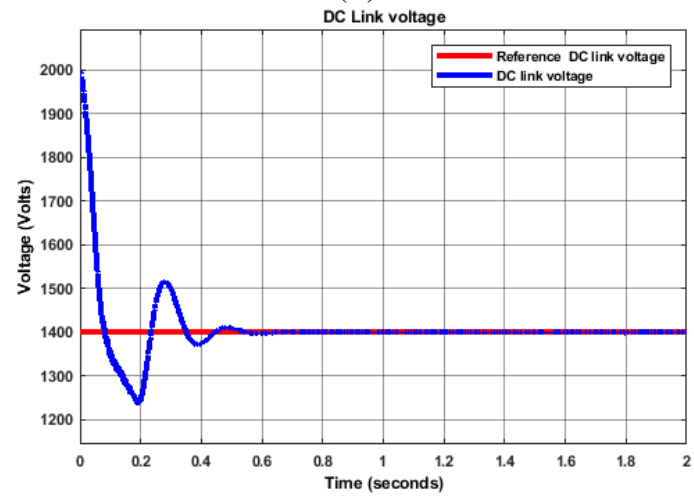

(B)

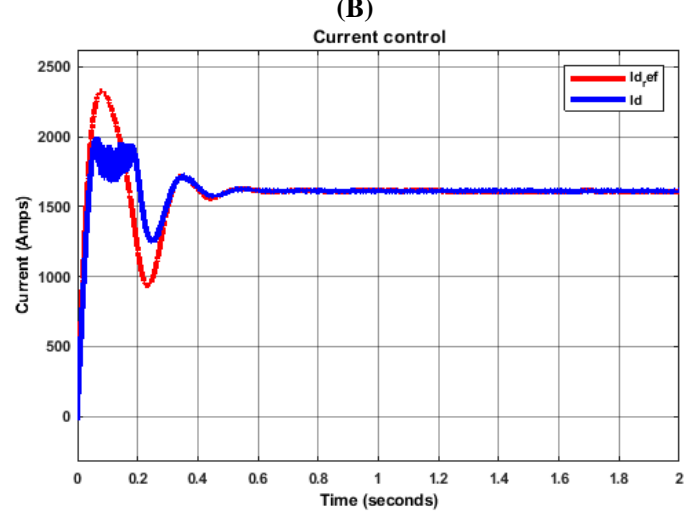

Fig. 15: Comparison of (A) Outer Control Loop and (B) Inner Control Against Their Reference Values.

The load and the grid active and reactive power are shown in Fig 16; for the load, the active power is about 1.26 MW (Fig. 16a), while the reactive power varies around zero (2.574e-8 VAR) (Fig. 16b). At the beginning of the simulation, the load active power response is characterized by an overshoot of $14.935 \%$ between the time $t=0$ and $t=0.3$ seconds and an undershoot of $2.468 \%$ between $t=0.3$ and $t=0.4$ seconds, thereafter, this response stabilizes to reach the steady state value of $1.26 \mathrm{MW}$. On the other hand, the reactive power displays an overshoot of $215.301 \%$, whereas the undershoot is $2.332 \%$. Regarding the grid; the active power supplied is about $21 \mathrm{~kW}$ (Fig. 16c), while the reactive is $13 \mathrm{kVAR}$ (Fig. 16d). These values represent the deficit power that the megawatt fuel cell is unable to supply to the load due losses occurring into the system, hence, the grid is operating as a support to complement the megawatt fuel cell system.

The active power response provided by the grid to the load is characterized by an overshoot of $11.728 \%$ between the time $t=0$ and $t=0.3$ seconds and an undershoot of $1.998 \%$ between $t=0.3$ and $t=0.4$ seconds, thereafter, this response stabilizes to reach the steady state value of $21 \mathrm{~kW}$. Similarly, the reactive power provided by the grid to the load displays an overshoot of $136.026 \%$, whereas the undershoot is $6.189 \%$. 
(A)
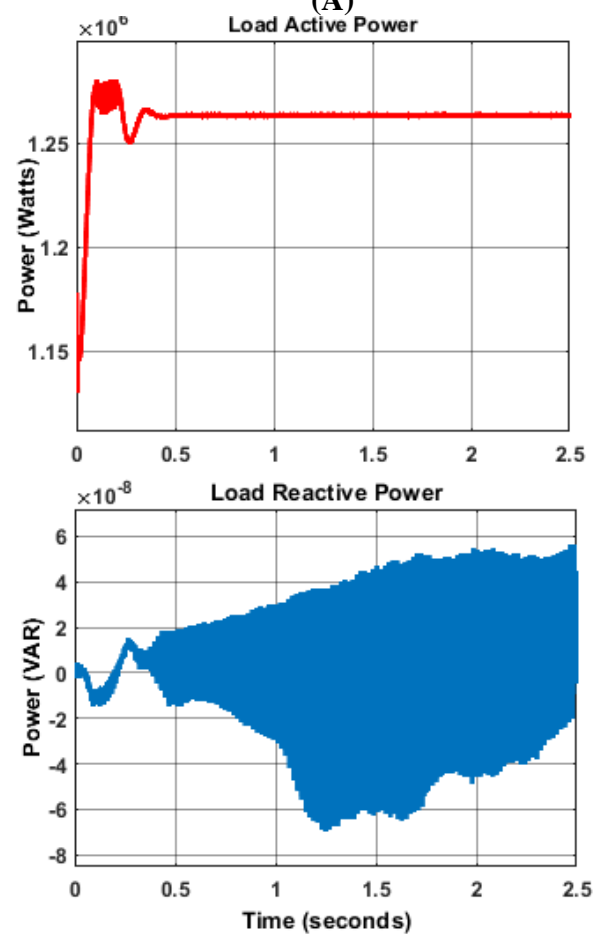

(B)


Fig. 16: (A) Load active and reactive power and (B) Grid active and reactive power.

\section{Conclusion}

The future development in the energy sector is founded on the utilization of renewable and sustainable energy sources. These energy sources can empower to meet the double targets of diminishing greenhouse gas emissions and ensuring reliable and cost-effective energy supply. Fuel cells are one of the advanced clean energy technologies and have demonstrated their ability to be a decent substitute to address the above-mentioned concerns. They are viewed as reliable and efficient technologies to operate either tied or non-tied to the grid and power applications ranging from domestic, commercial to industrial. Among different fuel cell technologies, proton exchange membrane is the most attractive. Its connection to the utility grid requires that the power conditioning system serving as the interface between the stack and the grid operates accordingly. This study aimed to model and control a power conditioning system for the grid-connection of a megawatt fuel cell stack. The system consisted of a 1.54 MW/1400 V DC proton exchange membrane fuel cell stack, a 1.3 MW/600 V three-level diode clamped inverter and an LCL filter which is designed to reduced harmonics and meet the standards such as IEEE 519 and IEC 61000-3-6. The power conditioning control scheme comprised voltage and current regulators to provide a good power factor and satisfy synchronization requirements with the grid. The frequency and phase were synchronized with those of the grid through a phaselocked-loop. The modelling and simulation were carried out using Matlab/Simulink environment. The results showed good performance of the proposed system with a low total harmonic distortion of about $0.35 \%$ for the voltage and $0.19 \%$ for the current.

The phase-to-phase AC voltage obtained at the output of the inverter without a filtering device displayed a peak to peak value is about $2800 \mathrm{~V}$, hence, the maximum and minimum values were $+1400 \mathrm{~V}$ and $-1400 \mathrm{~V}$ respectively, while the RMS voltage was about $938 \mathrm{~V}$. This voltage showed a total harmonic distortion of about $44.99 \%$ for frequencies up to $5 \mathrm{kHz}$ when the fundamental is $50 \mathrm{~Hz}$. This percentage was far above the limit as set by standards such as IEEE 519 and IEC 61000-3-6. To comply with the above-mentioned standards, an LCL low pass filter was designed connected at the output of the inverter. The phase-to-phase voltages and the current after filtering exhibited magnitudes of about $600 \mathrm{~V}$ and $1200 \mathrm{~A}$ for the voltage and the current respectively.

\section{References}

[1] Raji AK, Kahn MT. Analysis of distributed energy resources for domestic electricity users. J South Africa 2012;23:50-5. https://doi.org/10.17159/2413-3051/2012/v23i2a3163.

[2] Luta DN, Raji AK. Optimal sizing of hybrid fuel cell-supercapacitor storage system for off-grid renewable applications. Energy 2018;166:530-40. https://doi.org/10.1016/j.energy.2018.10.070.

[3] Ben Hamad K, Taha MH, Almaktoof A, Kahn MTE. Modelling and analysis of a grid-connected Megawatt Fuel Cell stack. 2019 Int. Conf. Domest. Use Energy, IEEE; 2019, p. 147-55.

[4] Lee K-B, Lee J-S. Reliability Improvement Technology for Power Converters. Singapore: Springer; 2017. https://doi.org/10.1007/978-981-10-49927.

[5] Mancilla-David F, Arancibia A, Riganti-Fulginei F, Muljadi E, Cerroni M. A maximum power point tracker variable-dc-link three-phase inverter for grid-connected PV panels. IEEE PES Innov. Smart Grid Technol. Conf. Eur., IEEE; 2012, p. 1-7. https://doi.org/10.1109/ISGTEurope.2012.6465892

[6] Hassaine L, Olias E, Quintero J, Salas V. Overview of Power Inverter Topologies and Control Structures for Grid Connected Photovoltaic Systems. Renew Sustain Energy Rev 2014;30:796-807. https://doi.org/10.1016/j.rser.2013.11.005.

[7] Yang Y, Blaabjerg F. Overview of Single-Phase Grid-Connected Photovoltaic Systems. Electr Power Components Syst 2015;42:11. https://doi.org/10.1080/15325008.2015.1031296.

[8] Jeong H-G, Lee K-B, Choi S, Choi W. Performance Improvement of LCL -Filter-Based Grid-Connected Inverters Using PQR Power Transformation. IEEE Trans Power Electron 2010;25:1320-30. https://doi.org/10.1109/TPEL.2009.2037225.

[9] Bao C, Ruan X, Wang X, Li W, Pan D, Weng K. Step-by-Step Controller Design for LCL-Type Grid-Connected Inverter with Capacitor-CurrentFeedback Active-Damping. IEEE Trans Power Electron 2013;29:1239-53. https://doi.org/10.1109/TPEL.2013.2262378. 
[10] Dhar S, Dash PK. Adaptive backstepping sliding mode control of a grid interactive PV-VSC system with LCL filter. Sustain Energy, Grids Networks 2016;6:109-24. https://doi.org/10.1016/j.segan.2016.03.001.

[11] Hamoud F, Doumbia ML, Cheriti A. Power factor improvement in WECS using cascade PI control of passive damping LCL-filter. 2015 Int Conf Sustain Mobil Appl Renewables Technol SMART 2015 2016. https://doi.org/10.1109/SMART.2015.7399267.

[12] Yao W, Member S, Yang Y, Zhang X. Design and Analysis of Robust Active Damping for LCL Filters Using Digital Notch Filters. IEEE Trans Power Electron 2017;32:2360-75. https://doi.org/10.1109/TPEL.2016.2565598.

[13] Sahoo HK, Subudhi U. Power System Harmonics Estimation Using Adaptive Filters. Compend. New Tech. Harmon. Anal., Intech Open Access; 2018. https://doi.org/10.5772/57353.

[14] Colak I, Kabalci E, Bayindir R. Review of multilevel voltage source inverter topologies and control schemes. Energy Convers Manag 2011;52:111428. https://doi.org/10.1016/j.enconman.2010.09.006.

[15] Dicks AL, Rand DAJ. Fuel Cell Systems Explained. 3rd ed. Wiley; 2018. https://doi.org/10.1002/9781118706992.

[16] Harrag A, Messalti S. How fuzzy logic can improve PEM fuel cell MPPT performances? Int J Hydrogen Energy 2018;43:53750. .https://doi.org/10.1016/j.ijhydene.2017.04.093

[17] Frappé E, De Bernardinis A, Coquery G, Bethoux O, Marchand C. Corrective Action with Power Converter for Faulty Multiple Fuel Cells Generator Used in Transportation. 2010 IEEE Veh. Power Propuls. Conf. VPPC 2010, Lille: 2010. https://doi.org/10.1109/VPPC.2010.5729037.

[18] Novak M, Šunde V, Jakopović Ž. Model of three level neutral point clamped converter ( NPC ) for grid connected photovoltaic systems. 2015 38th Int. Conv. Inf. Commun. Technol. Electron. Microelectron., Opatija: IEEE; 2015, p. 25-9. https://doi.org/10.1109/MIPRO.2015.7160248.

[19] Chaturvedi P, Shailendra Jain, Pramod Agrawal. Modeling, simulation and analysis of three-level neutral point clamped inverter using Matlab/Simulink/power system blockset 2008:1223-1227 Vol. 2. https://doi.org/10.1109/ICEMS.2005.202742.

[20] Aly M, Ramadan HA. Design and Implementation of Adaptive SVPWM Algorithm for Multilevel Inverters in Renewable Energy Applications. Sol Energy 2019;183:745-54. https://doi.org/10.1016/j.solener.2019.03.069.

[21] Buau X, Wang X, Pan D, Yang D, Li W, Bao C. Control Techniques for LCL-Type Grid- Connected Inverters $2018: 319$.

[22] Azani H, Massoud A, Benbrahim L, Holiday D, Williams BW. An active damping approach for PR-based current control of grid-tied VSI with LCL filter. 8th IET Int. Conf. Power Electron. Mach. Drives, Glasgow: 2016. https://doi.org/10.1049/cp.2016.0151.

[23] Bouchafaa F, Beriber D, Boucherit MS. Modeling and control of a gird connected PV generation system. 18th Mediterr. Conf. Control Autom. MED'10 - Conf. Proc., IEEE; 2010, p. 315-20. https://doi.org/10.1109/MED.2010.5547687.

[24] Abd K, Wahid E. LCL Filter Design With Passive Damping For Photovoltaic Grid Connected Systems. 6th Int. Renew. Energy Congr., vol. 2, 2015.

[25] Liu J, Zhou L, Yu X, Li B, Zheng C. Design and analysis of an LCL circuit-based three-phase grid-connected inverter. IET Power Electron 2016;10:232-9. https://doi.org/10.1049/iet-pel.2016.0351.

[26] Tarasantisuk C, Suyata T, Tarateeraseth V, Witheephanich K. Active and Reactive Power Control for Three-Phase Grid Inverters with Proportional Resonant Control Strategies. 2016 13th Int. Conf. Electr. Eng. Comput. Telecommun. Inf. Technol., Chiang Mai: IEEE; 2016 , p. 1-6. https://doi.org/10.1109/ECTICon.2016.7561379.

[27] Reznik A, Simoes MG, Al-Durra A, Muyeen SM. LCL Filter Design and Performance Analysis for Grid-Interconnected Systems. IEEE Trans Ind Appl 2014;50:1225-32. https://doi.org/10.1109/TIA.2013.2274612.

[28] Benzazah C, Lazrak L, Ait M. Design and Performance Analysis of Energy Conversion Chain , from Multilevel Inverter until the Grid. 2015 27th Int. Conf. Microelectron., Casablanca: IEEE; 2015, p. 311-4. https://doi.org/10.1109/ICM.2015.7438051.

[29] Kantar E, Usluer SN, Hava AM. Design and performance analysis of a grid connected PWM-VSI system. 2013 8th Int. Conf. Electr. Electron. Eng., vol. 2, The Chamber of Turkish Electrical Engineers-Bursa; 2014, p. 157-61. https://doi.org/10.1109/ELECO.2013.6713823.

[30] Zou Y, Qin J, Zhang L, Zhang Z. Novel Control Approach for Modular Multilevel Converter Based on $\alpha \beta 0$ Reference Frame Without PLL. 2018 IEEE Energy Convers. Congr. Expo., Portland, OR: 2018, p. 3044-9. https://doi.org/10.1109/ECCE.2018.8557431.

[31] Yang Y, Kim KA, Blaabjerg F, Sangwongwanich A. Advances in Grid-Connected Photovoltaic Power Power Conversion Systems. 2019. https://doi.org/10.1192/bjp.112.483.211-a.

[32] Hani S El, Mediouni H, Echchaachouai A. Comparative Analysis on Current Control Methods Grid Energy Quality. 3rd Int. Conf. Electr. Inf. Technol. ICEIT'2017 Comp., 2017.

[33] Al-Shetwi AQ, Sujod MZ, Blaabjerg F, Yang Y. Fault Ride-Through Control of grid-connected Photovoltaic Power Plants: A review. Sol Energy 2019;180:340-50. https://doi.org/10.1016/j.solener.2019.01.032.

[34] Ali Z, Christo N, Hadjidemetriou L, Kyriakides E, Yang Y. Three-phase phase-locked loop synchronization algorithms for grid- connected renewable energy systems : A review. Renew Sustain Energy Rev 2018;90:434-52. https://doi.org/10.1016/j.rser.2018.03.086.

[35] Al-Durra A, Reznik A, Simoes MG, Muyeen SM. Performance analysis of a grid-tied inverter for renewable energy applications. IECON Proc (Industrial Electron Conf 2014:4981-7. https://doi.org/10.1109/IECON.2014.7049256. 